\title{
頝椎・頝髄損傷における軟部陰影の検討
}

\author{
総合せき損センター整形外科 \\ 小橋 芳 浩・芝啓一郎 \\ 香月正昭・植田尊善 \\ 吉 浦 光 三. \\ 三尾母 英 幸・安 部 哲 一 \\ 青 野猛 \\ 山口赤十字病院 \\ 佐々木 邦 雄 \\ 角田整形外科 \\ 角 田信 昭
}

\section{Roentgenographic Soft Tissue Signs of Cervical Injury}

by

\author{
Yoshihiro Kohashi, Keiichiro Shiba, Masaaki Katsuki \\ Takayoshi Ueda, Kouzou Yoshiura, Hideki Ota \\ Hideyuki Miomo, Tetsuichi Abe, Takeshi Aono \\ Department of Orthopedic Surgery, \\ Spinal Injuries Center \\ Kunio Sasaki \\ Department of Orthopedic Surgery, \\ Yamaguchi red cross Hospital \\ Nobuaki Tsunoda \\ Tsunoda orthopedic Hospital
}

The lateral cervical roentgenogram is a useful guide in evaluating the bony and soft tissue relationships of the neck. Particularly, the measurements of the cervical soft tissue width are extremely important in determining the presence or absence of cervical spine injury. We therefore established the criterion of prevertebral soft tissue thickness. To determine the normal appearance, we examined 100 adults without detectable abnormalities in our clinic. We measured 248 cases of the cervical injury that had had operative treatment in our center. There were apparent differences in the results between these two groups. The prevertebral soft tissue width was measured at the level of the anteroinferior border of the second and sixth cervical vertebral body, the former is retropharyngeal space and the latter is retrotracheal space. This point was chosen because it was above the pharynx and the trachea, easy to determine, and free from conflicting shadows. It is suggested that measurments for the retropharyngeal space greater than $4 \mathrm{~mm}$, and measurments of the retrotracheal space greater than $15 \mathrm{~mm}$, should be indirect evidence of cervical spine injury. 
緒

言

頚椎・頚髄損傷（以下頚損と略す）におけるX線診 断の 1 つの指標として，軟部陰影の異常がある．特に， レントゲン的に見にくい下位頚椎の骨傷の場合有意義 であると言われている.しかし，本邦でのかかる軟部 陰影の計測の報告はみあたらない。そこで，軟部陰影 を, retropharyngeal space (以下 RP space) と retrotracheal space（以下RT space）とに分け， 検討した.

\section{対象及び方法}

過去 8 年間, 当センターにて, 手術的治療を施行し た，頚損 248 人を対象とした。骨傷の明らかでない例 （以下 I 群 98 人，骨傷の明らかな例（以下III群） 150 人, 男 212 人, 女 36 人, 年秢は, 14 才から 75 才, 平均 39才であった。 また，受傷より X線撮影までの期間は， 14 日以内とした. $\mathrm{X}$ 線撮影までの期間は, 平均 2.8 日 ( I 群2.9日，II群1.8日).コントロール群として， 外来患者を, at. randomに 100 人選んだ。計測には, 頚椎側面単純レントゲン像にて，それぞれの軟部陰影 の実測値を用いた. RP spaceは， $C_{2}$ 椎体下縁より, 咽頭後壁までの, RT space は, $\mathrm{C}_{6}$ 椎体下縁より, 気
管後壁までの直線距離で表わした。

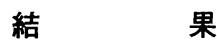

RP space において, I 群, 下位頚椎損傷タイプ (以下 II’群)，コントロール群では，それぞれの平均 值は, 6.54士2.44 SD, $5.59 \pm 2.20 \mathrm{SD}, 3.11 \pm 0.97$ $\mathrm{SD}$ であった。また，各々間に，明らかな有意差を認 めた（表1). 次に, RT spaceにおいて, I 群とコン トロール群では，それぞれの平均值は，14.97士3.26 $\mathrm{SD}, 12.53 \pm 2.44 \mathrm{SD}$ であり，また，この間にも明ら かな有意差を認めた（表 2). 次に, RP space と RT space との相関関係を調査した. I 群，II群ともに， 両者間に，正の相関関係がみられた（表 3 ). 次に，I 群において，手術時，前縦䩲帯の断裂の有無における RP spaceの拡大との関係を調査した。断裂のあった 群 (59例) の平均值は, $6.66 \pm 2.44 \mathrm{SD}$, 断裂のなか った群 (21例) の平均值は, $6.55 \pm 2.37 \mathrm{SD}$ であり, 両者間に，有意の差を認めなかった（表 4 ）.

症例

（症例 1 ）コントロール群. 27才女性. 頝部痛を主訴 として, 来院. 特に外傷の既応はない. RP space 3 mm, RT space $10 \mathrm{~mm}$ である（図 1 ）.

表 1 RP Space平均值とその有意差

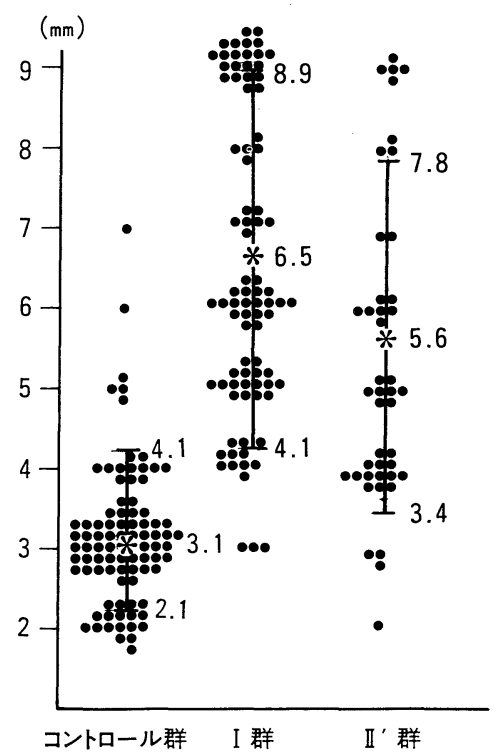

\begin{tabular}{|c|c|c|}
\hline & 平均值 $(95 \%)$ & 有意差 $\mathrm{T}$ 検 定 \\
\hline 群 & \multicolumn{2}{|c|}{$6.54 \pm 2.44 S D \longrightarrow P<0.001$} \\
\hline コントロール群 & $3.11 \pm 0.975$ & $0.005<P<0.01$ \\
\hline $\mathbb{I I}^{\prime}$ & $5.59 \pm 2.205$ & $P<0.001$ \\
\hline
\end{tabular}


表 2 RT Space平均値とその有意差

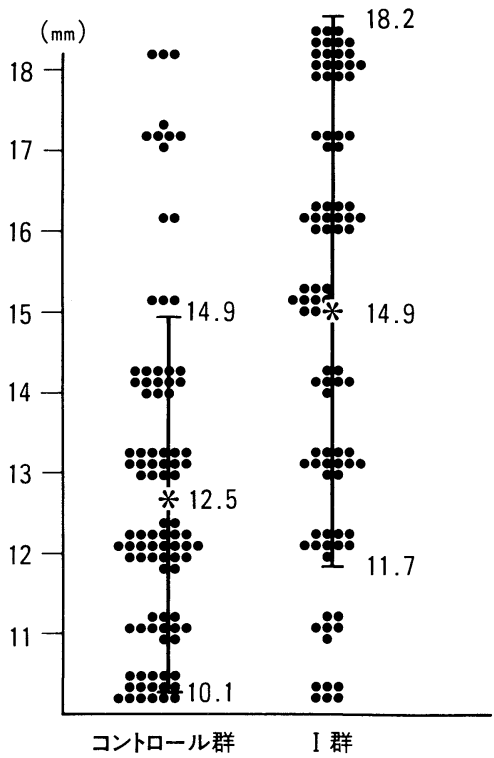

\begin{tabular}{|l|l|l|}
\hline & 平均值 (95\%) & 有意差 $\mathrm{T}$ 検定 \\
\hline コントロール群 & $12.53 \pm 2.44 \mathrm{SD}$ & \\
$\mathrm{I}$ & $\mathrm{I}$ & $\mathrm{P}<0.001$
\end{tabular}

表 3 I 群の RP space と RT space との相関関倸

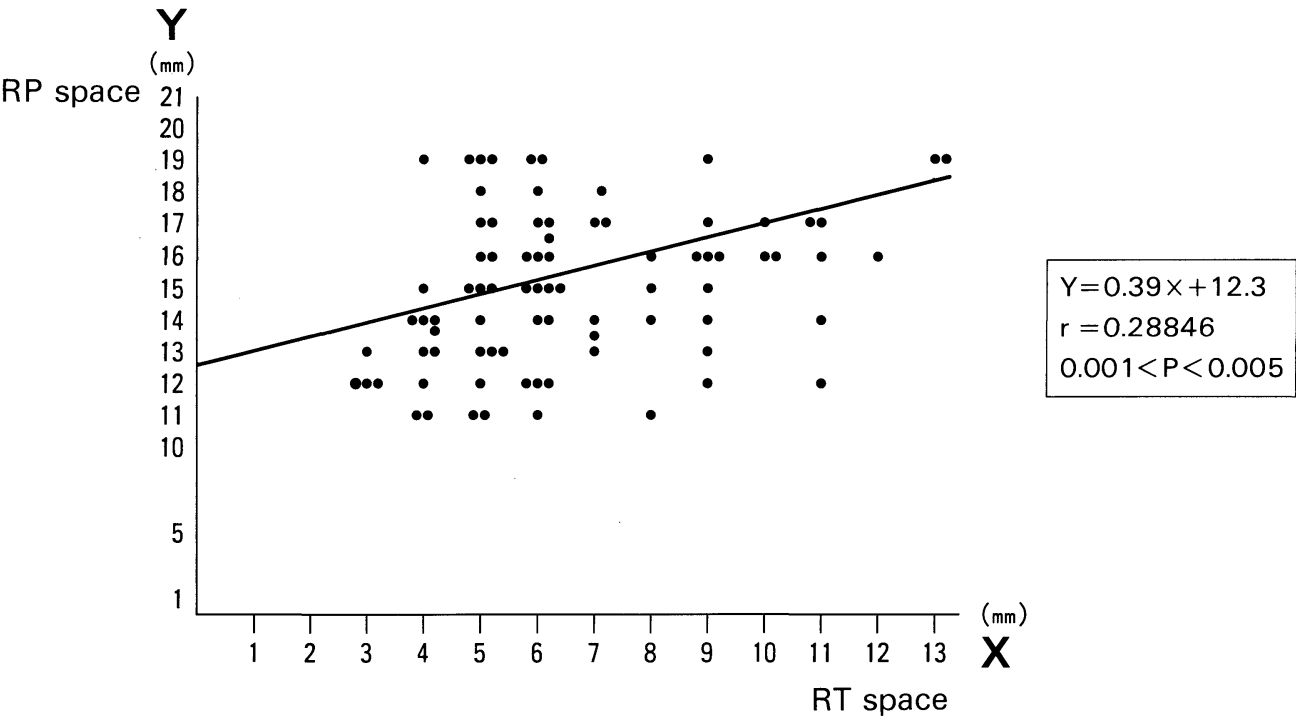


表 4 ALL ruptureの有無による $\mathrm{RP}$ spaceの差〈I群〉

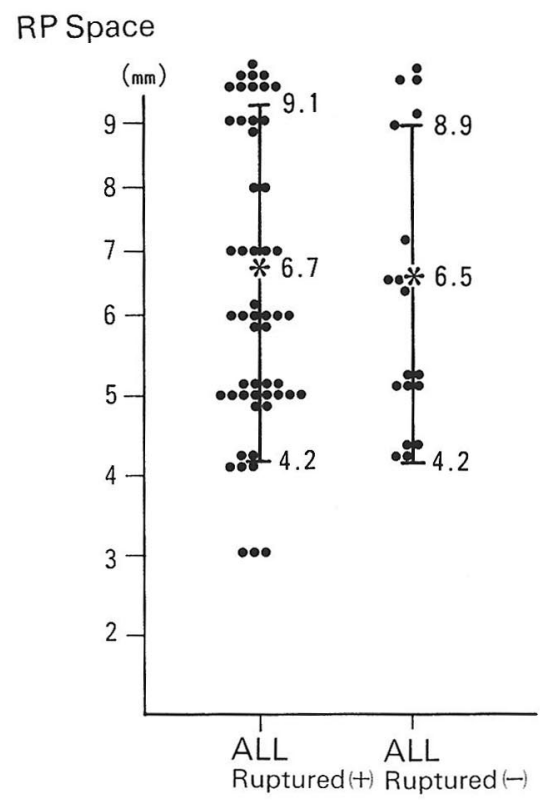

\begin{tabular}{|c|c|c|}
\hline & 平均値 $(95 \%)$ & 有 意 差 \\
\hline $\begin{array}{c}\text { ALL Ruptured } \\
(-)\end{array}$ & $6.66 \pm 2.44 \mathrm{SD}$
\end{tabular}$\rightarrow 0.8<\mathrm{P}<0.9$

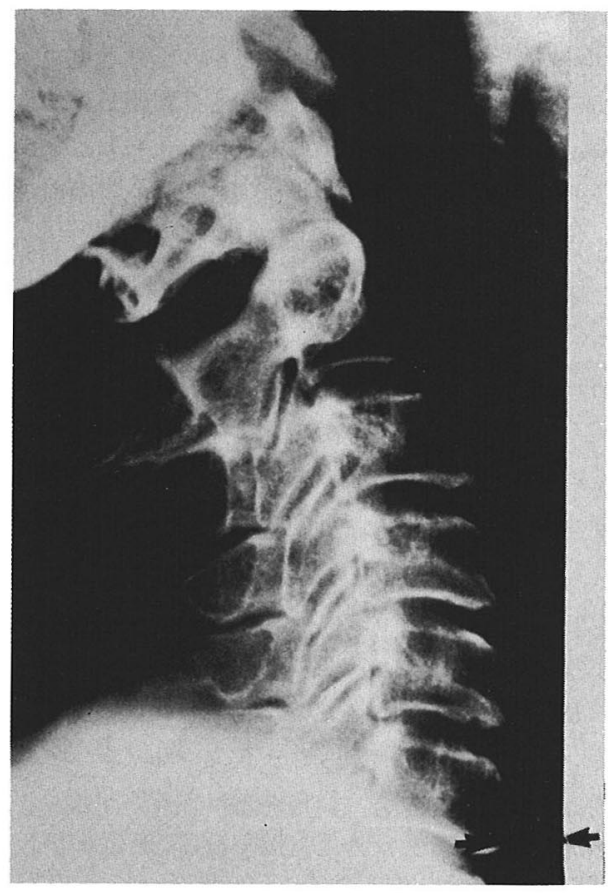

図 1 コントロール群 27 y. f.

retropharyngeal space $3 \mathrm{~mm}$ retrotracheal space $10 \mathrm{~mm}$

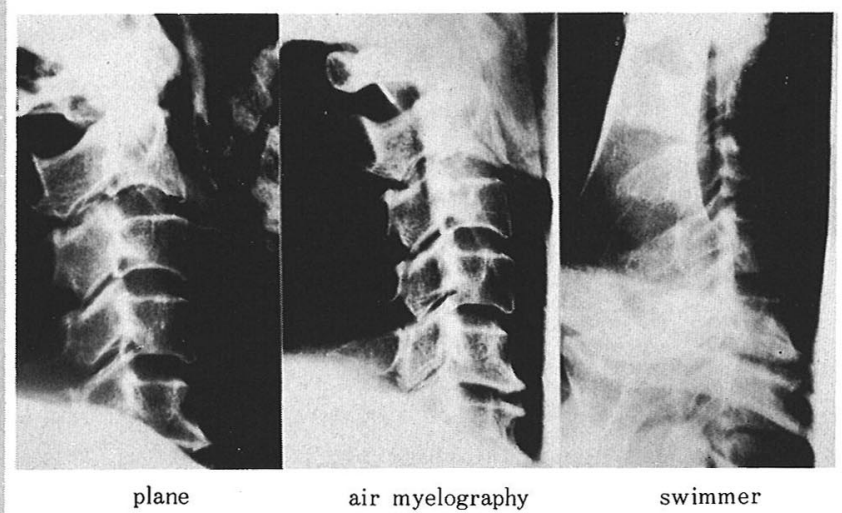

図 2 I 群 $55 \mathrm{y} . \mathrm{m}$. retropharyngeal space $11 \mathrm{~mm}$ retrotracheal space $16 \mathrm{~mm}$ 


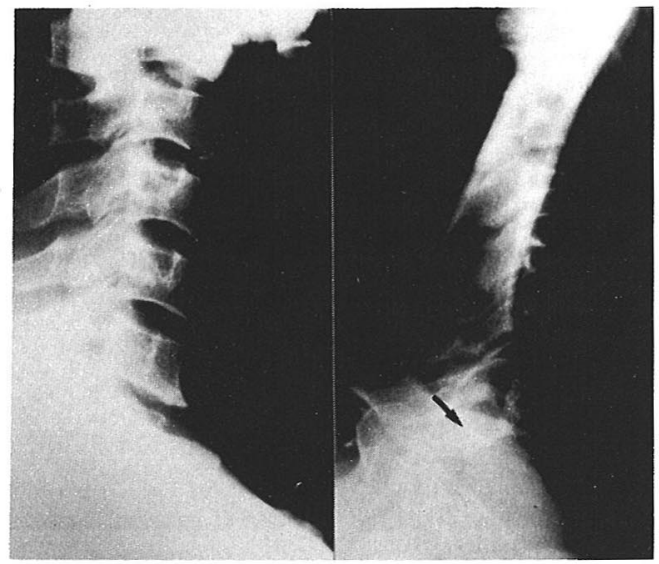

plane

swimmer

図 3 II 群

51 y. $\mathrm{m}$.

retropharyngeal space $10 \mathrm{~mm}$

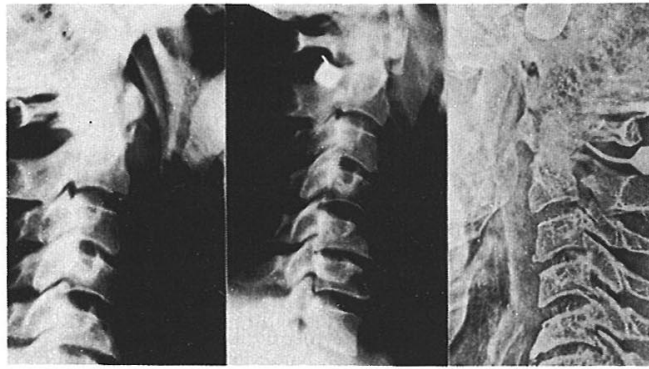

plane

airmyelography

xerography

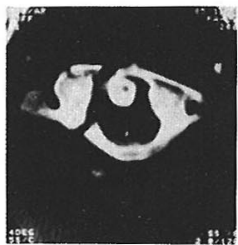

C. T.

図 4 III群

54 y. m.

retropharyngeal space $13 \mathrm{~mm}$ retrotracheal space $19 \mathrm{~mm}$

（症例 2) I 群. 55才男性. バイクにのっていて転倒 し受傷. 受傷後 4 日目に入院. RP space $11 \mathrm{~mm}, \mathrm{RT}$ space $16 \mathrm{~mm}$, air myelo にて, $\mathrm{C}_{3 / 4}, \mathrm{C}_{5 / 6}, \mathrm{C}_{6 / 7}$ に air の途絶像がみられる. $\mathrm{C}_{3 / 4}$ 及び $\mathrm{C}_{5-7}$ 前方固定術を 施行した. 術中 $\mathrm{C}_{3 / 4}, \mathrm{C}_{5 / 6}, \mathrm{C}_{6 / 7}$ にて, 前縦䩲帯の断 裂また同部の椎間板断裂が認められた（図 2 ).

（症例 3 ）II 群. 51才男性. 自転車にて転倒し受傷. 受傷当日入院. RP space $11 \mathrm{~mm}$, swimmer's view にて， $C_{6 / 7}$ 脱臼骨折がはっきりする(図3).

（症例 4 ）II群.54才男性. 高所より転落し受傷. 受 傷後 1 日目に入院. RP space $13 \mathrm{~mm}, \mathrm{RT}$ space 19 mm, air myeloにて, $C_{2 / 3}$ 以下, air の通過が悪く, CTにて， C 1 ring の骨折があり Jefferson type の骨 折であった（図 4 ).

\section{考察}

RP space, RT spaceは, 頭骨基部より, $\mathrm{T}_{1} \mathrm{~T}_{2} レ$ ベルの縦隔まで広がる, buccopharyngeal fascia と, prevertebral fascia に囲まれた, 軟部組織の陰影で ある $3^{3)}$ (図 5 )。この部は, 感染, 新生物, 内分泌異常, リンパ障害, そして外傷と広い分野にわたり影響を受 ける．外傷の場合，この部の軟部組織に，血腫，ある いは浮腫が発生し, 腫脹してくるものと思われる.

DON WEIR は，360人の整形外来患者を対象に， RP space の正常範囲を調查している。 それによると， $2.6 \mathrm{~mm}$ から $4.8 \mathrm{~mm}$ を正常とし， $5 \mathrm{~mm}$ 以上であれば, 頝損が疑わしいとしている は, 整形外来以外の患者も含め, 700 人のレントゲン 調查により, RP space の正常值は, $3.4 \mathrm{~mm}$, 範囲 1

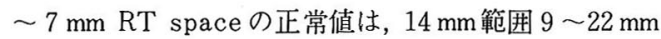
$\mathrm{RP}$ space $7 \mathrm{~mm}$ 以上, $\mathrm{RT}$ space $22 \mathrm{~mm}$ 以上であれ ば，何らかの異常が，軟部組織におきているとした ${ }^{2)}$. 今回, 我々が調査した結果では, 統計学上, RP space の正常値は, $4 \mathrm{~mm}$ 以下, RT space の正常值は, 15 $\mathrm{mm}$ 以下が妥当と思われる. 従って, RP space $4 \mathrm{~mm}$ 以上, RT space $15 \mathrm{~mm}$ 以上であれば, 軟部組織の腫 脹を示唆する所見といえる.つまり，澒損を念頭にお いての精査が必要である(図6). 特に, 下位頚椎損傷 時，レントゲン的に骨傷が，わかりにくい場合，また， 明らかな骨傷がない場合, 澒損を念頭におく一つの指 標になるのではないだろうか. また, RP space と RT space との間に, 正の相関関係が存在しており, これは，頚椎損傷レベルにかかわらず，RP，RT space の拡大は，頝損の指標とすることができると思われる． 

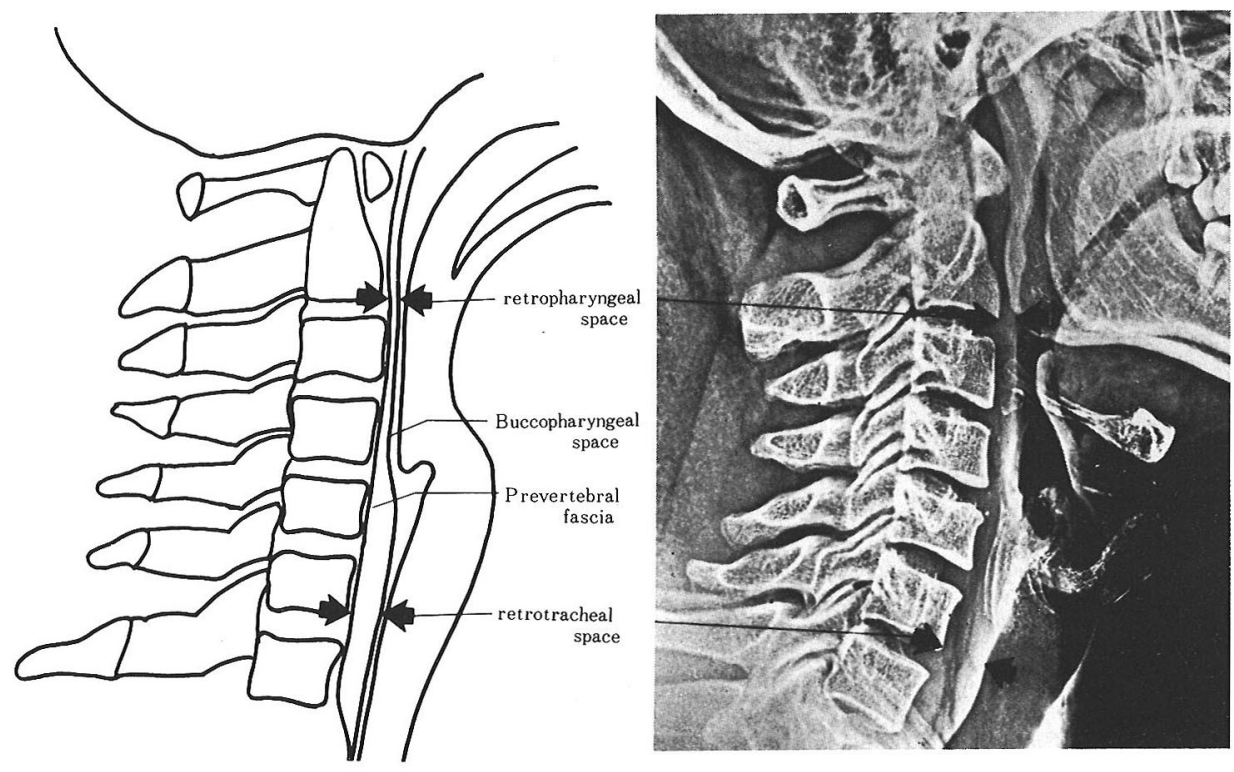

図 5 軟部陰影模式図及びZerography

DON C. WEIR

\begin{tabular}{|r|c|c|}
\hline$(\mathrm{mm})$ & Normal Range & $\begin{array}{c}\text { Cervical } \\
\text { injury }\end{array}$ \\
\hline $\begin{array}{c}\text { Retrapharyrgeal } \\
\text { space }\end{array}$ & $2.6 \sim 4.8$ & 5 以上 \\
\hline
\end{tabular}

MARK. H. WHOLEY. et al.

\begin{tabular}{|r|c|c|}
\hline & Normal (Adult) & Abnormal \\
\hline$(\mathrm{mm})$ & Averuge \& Range & \\
\hline $\begin{array}{r}\text { Retrapharyrgeal } \\
\text { space }\end{array}$ & $1<3.4<7$ & 7 以上 \\
\hline $\begin{array}{r}\text { Retrotracheal } \\
\text { space }\end{array}$ & $9<14.0<22$ & 22 以上 \\
\hline
\end{tabular}

Y. KOHASHI, K. SHIBA. et al.

\begin{tabular}{|c|c|c|c|c|}
\hline & control 群 & Non-visible & visible & cervical injury \\
\hline $\begin{array}{c}\text { Retrapharyrgeal } \\
\text { space }\end{array}$ & $3.97 \pm 0.97 \mathrm{SD}$ & $6.54 \pm 2.44 \mathrm{SD}$ & $5.59 \pm 2.20 \mathrm{SD}$ & $4 \mathrm{~mm}$ 以上 \\
\hline $\begin{array}{c}\text { Retrotracheal } \\
\text { space }\end{array}$ & $12.53 \pm 2.44 \mathrm{SD}$ & $14.97 \pm 3.26 \mathrm{SD}$ & - & $15 \mathrm{~mm}$ 以上 \\
\hline
\end{tabular}

図 6 


\section{ま と め}

(1) 頚椎, 頚髄損傷のX線側面像において, retropharyngeal space と retrotracheal space の軟部 陰影を計測した。

(2) 対象は, 頚損 248 人, 骨傷の明らかでない例 98 人, 骨傷の明らかな例 150 人，コントロール群として， 外来患者 100 人の X線像を, at randomに使用した.

(3) retropharyngeal space, retrotracheal space 共に正常例と䅡損例間に, 有意の差がみられた.

(4) retropharyngeal space, および retrotracheal spaceは，コントロール群では，それぞれ， $3.11 \mathrm{mm,}$ $12.53 \mathrm{~mm}$ であり, 骨傷の明らかでない群では, そ
れぞれ， $6.54 \mathrm{~mm}, 14.97 \mathrm{~mm}$, 骨傷の明らかな群で は, $5.59 \mathrm{~mm}$ であった。

(5) retropharyngeal space $4 \mathrm{~mm}$ 以上, retrotracheal space $15 \mathrm{~mm}$ 以上を䅡損の一つの指標とする ことができる.

\section{文献}

1) Weir, D. C. Roentgenographic Sign of Cervical injury, Clinical Orthopaedics, 109:9-17, 1975.

2) Wholey, M.H. The lateral roentgenogram of the Neck, Radiology, 71:350-356, 1958.

3) Wong, Y. K. Retropharyngeal space, The journal of otolaryngology, $7: 6,528-536,1978$. 